\title{
Role of Dilute Alcohol in the Removal of Fine Wrinkles from Paraffin Sections, a Histo-Technical Study
}

\author{
Rol del Alcohol Diluido en la Eliminación de Arrugas Finas \\ desde Secciones de Parafina, un Estudio Histotécnico \\ "Naveen Kumar; "Satheesha Nayak B.; "S. N. Somayaji \& **Sadananda Nayak
}

KUMAR, N.; NAYAK, B. S.; SOMAYAJI, S. N. \& NAYAK, S. Role of dilute alcohol in the removal of fine wrinkles from paraffin sections, a histo-technical study. Int. J. Morphol., 30(1):45-48, 2012.

SUMMARY: Histotechnology is concerned with processing and preparing of the body tissue in such a manner as to enable a satisfactory study of it. Section cutting is an integral part of histology and histopathology. It is an art by itself requiring skill and knowledge on the part of technician or the person who needs to do section cutting. In the routine method of preparing paraffin sections, it is often encountered by the presence of artefacts like fine wrinkles or folds. Attempts have been made to remove the wrinkles by floating the sections in the warm water bath. However this method has not been able to remove all the wrinkles from the sections. We have designed a simple and reliable method, in which the paraffin sections were floated over the ethyl alcohol diluted with water (1:15) before they were placed in the water bath. Through this method, we have been able to get the wrinkle free sections of superior quality. The advantage of our method is that, it is easy to prepare the dilute alcohol and is cost effective. This method can be used by the histology and pathology technicians and the researchers.

KEY WORDS: Histological techniques; Section cutting; Microtomy; Wrinkles; Dilute alcohol.

\section{INTRODUCTION}

Histotechnology deals with processing and preparation of the tissue of the body in such a manner as to enable a satisfactory study of it (Brown, 1978). Section cutting is an integral part of histology or histopathology. It is an art by itself requiring skill and knowledge. The skill and competency of the technician can contribute a lot towards the preparation of good quality slides.

One of the major problem encountered during the preparation of histology slides is the presence of folds or wrinkles on the paraffin sections. In the conventional method of sectioning, the sections are spread on a tissue flotation bath (water bath) with the temperature at approximately 34$38^{\circ} \mathrm{C}$ before they are mounted on the slide (Preece, 1959). The warm water assists in spreading out the section and removing wrinkles. However, many smaller wrinkles and air bubbles are trapped in the sections while it is being laid on the water bath surface. Prolonged stretching of the paraffin ribbon also causes, crack and tear. This would create gaps and cracks which the pathologist or researcher has to proportion back together under the microscope. Such an undertaking would be tedious and time consuming.
The laboratory technicians use several items such as an artist's camel hair brush, a metal probe, the technician's fingers and cotton swabs to remove these tiny wrinkles and bubbles from the paraffin ribbons. However each of these methods has its own drawbacks.

In the present study we used absolute ethyl alcohol and water (1:15) mixture as a pretreatment to the sections before they were transferred to tissue flotation bath and compared them with the routinely prepared slides.

\section{MATERIAL AND METHOD}

Experimental design. In our study, we studied 50 sections prepared from 25 different types of tissues. These tissues were categorized into 4 groups

Group A- blood containing tissues such as spleen $(n=5)$

Group B- friable tissues such as brain and lymphnode $(n=5)$ Group C- hard tissues such as thyroid and uterus $(n=8)$

\footnotetext{
* Department of Anatomy, Melaka Manipal Medical College (Manipal Campus), Manipal University, Manipal, India.

** Department of Pathology, Kasturba Medical College, Manipal University, Manipal, India.
} 
Group D- other tissues such as ureter, appendix and fallopian tube $(n=7)$

Histological procedure. Tissues from each group were processed for light microscopic study which began with fixation by $10 \%$ formalin, dehydration through graded ethyl alcohol, clearing by xylene and impregnation with paraffin wax. All the tissues were embedded in paraffin wax. Careful observation was done at the end of each stage of processing to ensure the proper processing.

Preparation of dilute alcohol solution. One volume of absolute ethyl alcohol (ethanol) was mixed with 15 volumes (1:15 dilution) of water. This solution was kept in the rectangular Coplin jar. It was prepared freshly as and when it was needed

Microtomy procedure. Paraffin blocks of the tissues were prepared. Ribbons of 5 Micron thick sections were obtained by cutting the block on a Minot Rotory microtome. The ribbon was divided into two parts and proceeded as follows.

First part of the ribbon. The sections of this part of the ribbon were directly transferred to the water bath (tissue flotation bath) heated to $34-38^{\circ} \mathrm{C}$. It is allowed to flatten by gentle pressure applied through blunt forceps. Maximum effort of removing wrinkles was made before taking the section onto adhesive applied glass slides as a part of mounting.

Second part of the ribbon. Sections of this part of the ribbon were floated on the dilute alcohol solution for 3-5 minutes and they were then transferred to the water bath. From the water bath, the sections were taken on an adhesive applied glass slide.

Both sets of slides were deparaffinised and stained with routine $\mathrm{H} \& \mathrm{E}$ staining technique. After staining, the mounting procedure was done using DPX. The sections were observed under light microscope for the presence of folds or minor wrinkles.

\section{RESULTS}

The sections of the first part of the ribbon had minute folds and wrinkle whereas the sections of the second part of the ribbon did not have any folds or wrinkles. This was evident in all the tissues that we studied (Figs. 1-3).

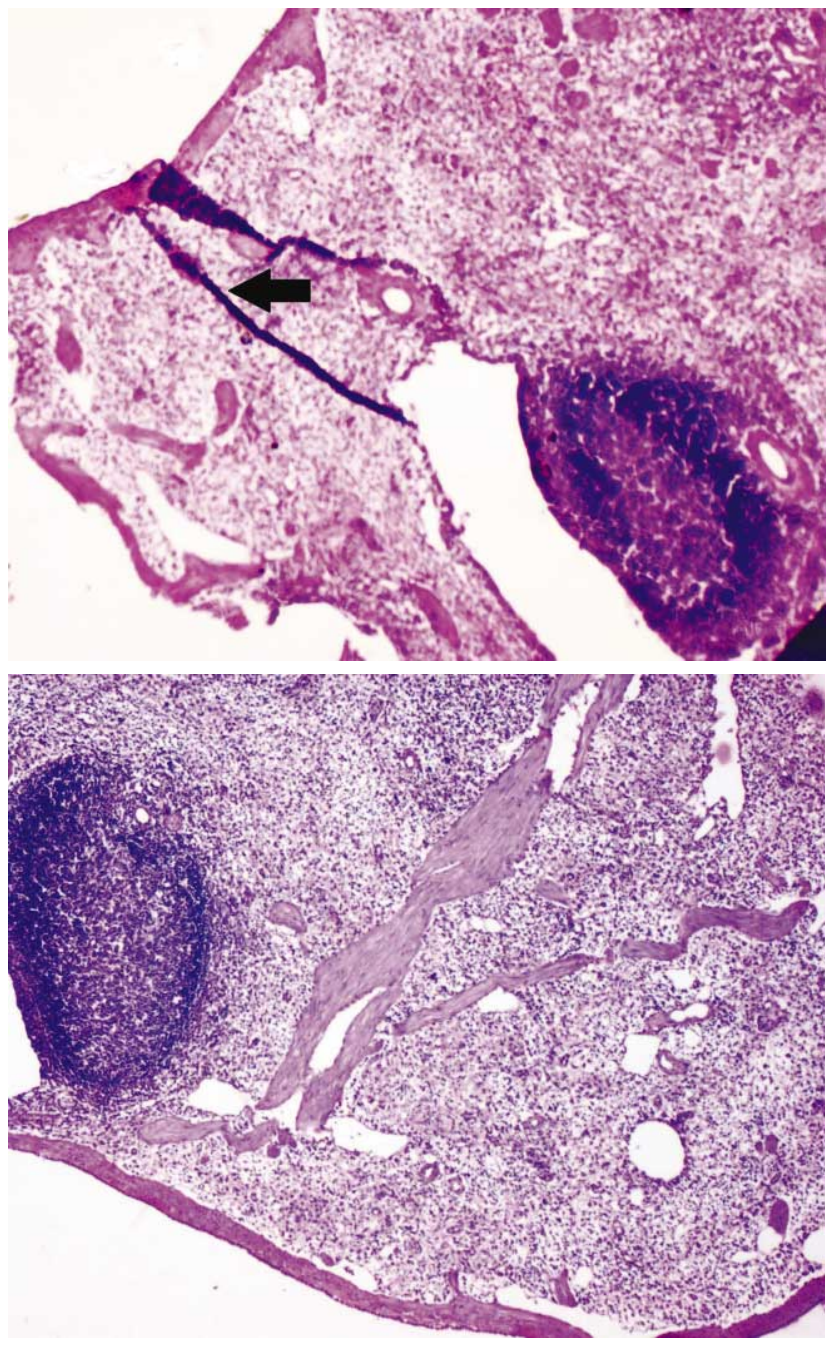

Fig. 1. Comparing the sections from spleen (group A). Note thick arrow showing fold in untreated section compared to no folds or wrinkles in alcohol treated section (H\&E, 100X).

\section{DISCUSSION}

When a piece of tissue or organ is sent to histology or histopathology laboratory for the histological study, in the lab, these specimens pass through series of dehydrating alcohols, clearing chemicals and molten paraffin wax. Paraffin block is then prepared and thin sections are obtained from it by means of microtomy.

The process of section cutting is referred as "the art of microtomy", involves basic requirements such as: well maintained microtome, sharp knife, properly processed blocks and more than all the skill and experience of section cutting. The technician obtains the skill and expertise by constant practice in the art of microtomy. 


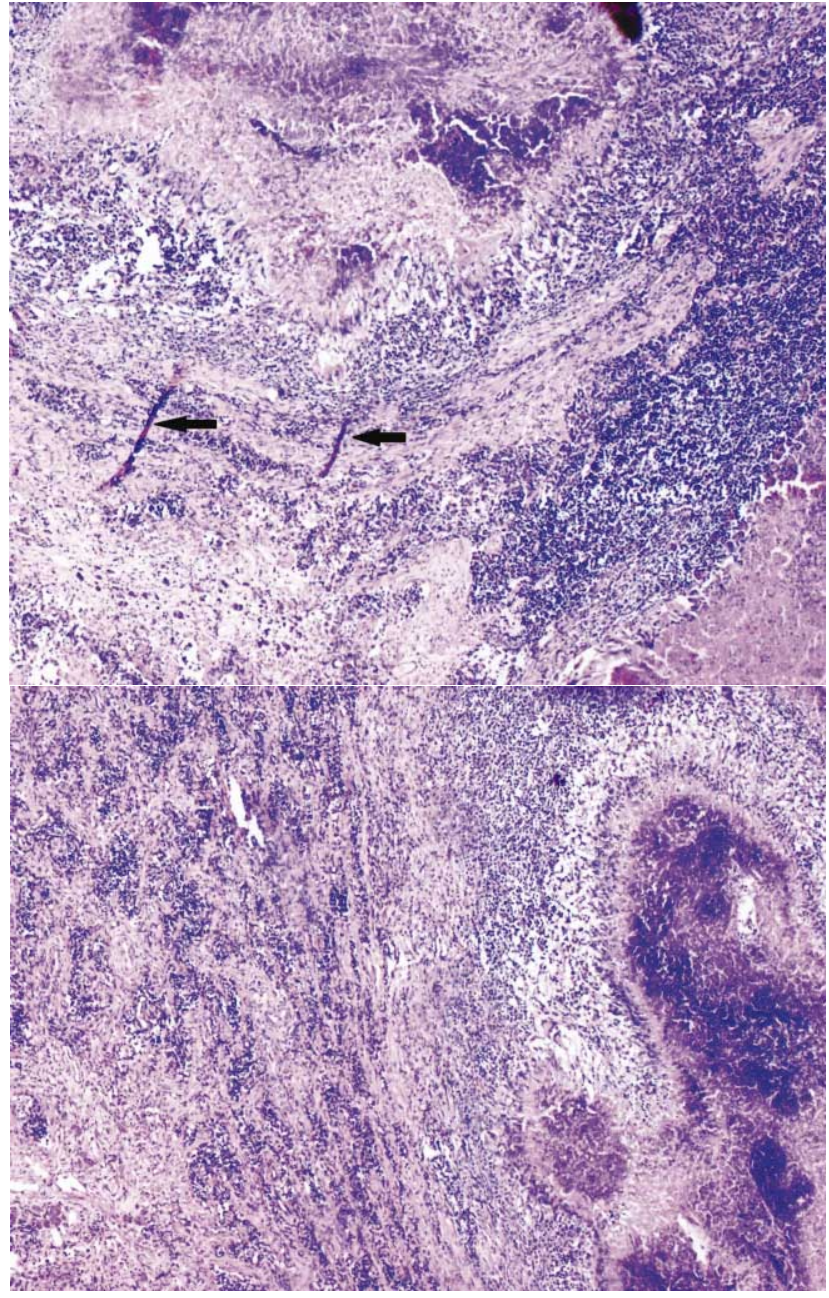

Fig. 2. Comparing the section of Lymph node (from group B). Note thin arrows showing minor wrinkles in untreated section compared to no wrinkles in alcohol treated section (H\&E, 100X).

Although the majority of the blocks of tissue are easily sectioned without any artefacts by conventional method of sectioning, there are occasions when poor quality sections are cut. Faulty equipment, poor technique and faulty processing of the tissue are some of the major causes for the poor sections. Despite of proper processing, it is very common to have artefacts like minor folds or wrinkles in the sections due to faulty microtomy. These faults may lead to loss of important morphological information about the cell lines of particular interest and often mislead to wrong interpretation. Hence, an adequate skill in the section cutting is an integral part of histological practice especially in pathological condition. The diagnosis of the disease is frequently made based on the studies of the histological section and this can alter the course of life for a patient and his family, often irreversibly. This also implies to the researchers, who handle valuable tissue as part of their research but with inadequate experience in sectioning. Therefore, the pathologist or research scholar who deals with
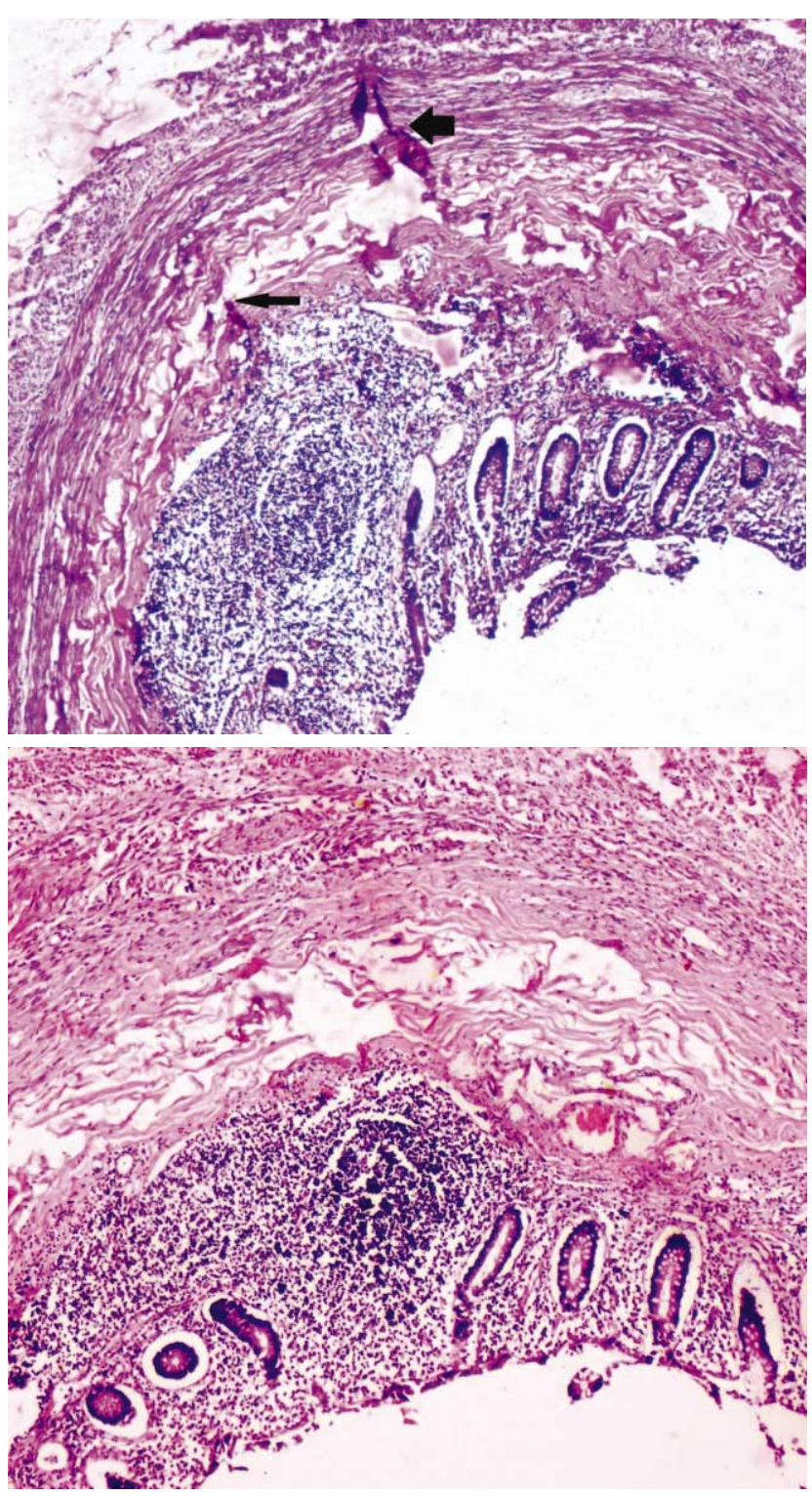

Fig. 3. Comparing the section of appendix (from group D). Note thick arrow showing fold and a thin arrow showing minor wrinkle in untreated section, whereas no wrinkles in alcohol treated section (H\&E, 100X).

the histological aspects is rendered helpless in the face of a 'bad section'.

In the routine practice, sections obtained by the process of microtomy, are floated out in the flotation bath with a temperature $34-38^{\circ} \mathrm{C}$. The slight drag produced when the ribbon is laid on the water is sufficient to remove most, if not all of the folds that may occur. The folds are removed by gently teasing the sections with the blunt forceps. Thirty seconds should be long enough time for a section to flatten. If the time on the water is prolonged the section may expand unduly and cause distortion to the tissue (Bancroft \& Gamble, 2002.) 
Several methods have been adopted in the histology laboratory for removing tiny wrinkles and bubbles from the paraffin ribbons. However, each of these methods may lead to one or the other problem that may alter the final interpretation. In some laboratories, the process known as 'hot stage method' is used for the removal of wrinkles. In this method, albumenized slide is placed over the metal top of hot stage, heated by gas or electrically. Slide is flooded with distilled water and section is laid on the surface of the water. Under the influence of heat, the smaller creases disappear and section will be flattened out (Culling, 1974). However heating method often leads to adverse effect on the sections. To avoid such technical errors, it is advisable to have a simple interventional procedure to remove minor wrinkles or folds in the sections so that, persons without proper skill on section cutting technique can also prepare good quality slides. According to Lynch (1969), for the beginners or in case of difficulties to remove the stubborn wrinkles, sections may be transferred to $70 \%$ alcohol for a few seconds followed by conventional method of stretching the section in water bath. So when returned to water the deference in the surface tension rapidly unfurls them. However he suggested this technique for the frozen sections. Bancroft \& Gamble suggested pre-flooding the sections in 50\% alcohol. The slide is then gently immersed in the water bath. The presence of alcohol in close proximity to the section sets up diffusion currents that help flatten the section.

In our study, we used 1:15 diluted alcohol and applied this technique for all 4 groups of tissues. The advantage of our method is that the concentration of alcohol required is less than 7\%. This modification gives excellent results similar to the higher concentrations of alcohols used in earlier studies. This technique is simple, safe and reliable method than any other technique as well as it does not need any machinery. This method can be used by researchers and relatively inexperienced technicians because it is easy to prepare and use the reagent. The successful research and diagnosis that is based on histology slides depends on the skill and competency of the technician. Our innovative technique of using dilute alcohol to remove the wrinkles and folds is very economical and easy to adopt. This technique can contribute a lot towards the success of histology based research and diagnosis.

KUMAR, N.; NAYAK, B. S.; SOMAYAJI, S. N. \& NAYAK, S. Rol del alcohol diluido en la eliminación de arrugas finas desde secciones de parafina, un estudio histotécnico. Int. J. Morphol., 30(1):45-48, 2012.

RESUMEN: Histotecnología se refiere a la elaboración y preparación de los tejidos del cuerpo de tal forma que permitan un estudio satisfactorio de éste. El corte seccionado es una parte integral de la histología y la histopatología. Es un arte por sí mismo que requiere habilidad y conocimiento por parte del técnico o la persona que tiene que hacer el corte de la sección. En el método de rutina de la preparación de las secciones de parafina se encuentra a menudo la presencia de artefactos como arrugas finas o pliegues. Se han hecho intentos para eliminar las arrugas por flotación de las secciones en el baño de agua tibia. Sin embargo, este método no ha sido capaz de eliminar todas las arrugas de las secciones. Hemos diseñado un método sencillo y fiable, en el que las secciones de parafina fueron colocadas por flotación sobre alcohol etílico diluido con agua (1:15) antes de ser colocado en el baño de agua. A través de este método, hemos sido capaces de obtener secciones sin arrugas de calidad superior. La ventaja de nuestro método es que, es fácil de preparar el alcohol diluido y es rentable. Este método puede ser utilizado por los técnicos de histología, patología e investigadores.

PALABRAS CLAVE: Técnicas histológicas; Corte de la sección; Microtomía; Arrugas; Dilución en alcohol.

\section{REFERENCES}

Bancroft, J. D. \& Gamble, M. Theory and practice of histological techniques. $5^{\text {th }}$ ed. Edinburgh, Churchill Livingstone, 2002. pp.95-7.

Brown, G. An introduction to histotechnology. New York, Appleton Century Crofts, 1978. p.149-50.

Culling, C. F. A. Hand book of histopatholgical and histochemical techniques. $3^{\text {rd }}$ ed. London, Butterworth \& Co., 1974. pp.129-31.

Lynch, M. J. Medical laboratory technology and clinical pathology. $2^{\text {nd }}$ ed. Philadelphia, W. B. Saunders, 1969. pp.946-7.
Preece, A. A Manual for histologic technicians $1^{\text {st }}$ ed. Boston, Little Brown and Company, 1959. pp.46-8.

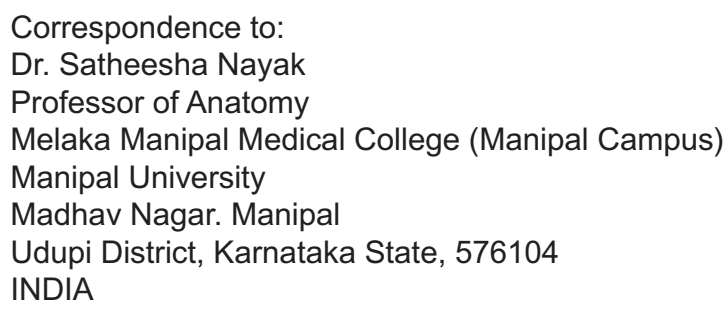

Received: 02-09-2010

Accepted: 20-07-2011 